\title{
De architectuur van uitbestedingscontracten
}

\section{Henri Dekker}

SAMENVATTING Dit artikel bespreekt het ontwerp van contractuele beheersingsstructuren voor transacties tussen ondernemingen. Met behulp van uitgebreide enquêtedata over transacties in informatietechnologie wordt geanalyseerd hoe kopers en leveranciers contracten voor hun transacties vormgeven, hoe karakteristieken van de transactie(partners) op contractontwerp van invloed zijn en of transacties met weinig en veel ex post transactieproblemen van elkaar verschillen in contractontwerp. De analyses duiden aan dat contractafspraken worden gemaakt in regelmatig voorkomende combinaties met eenzelfde doel, die verschillende dimensies van beheersing weergeven. Transactiepartners maken meer gebruik van contractafspraken bij een toename van de financiële omvang, specificiteit, onzekerheid en taakcomplexiteit van de transactie. De contracten van succesvolle transacties blijken daarbij meer te worden aangepast aan de verschillende karakteristieken van de transactie(partners) dan die van minder succesvolle transacties. Vooral voldoende aandacht voor transactieonzekerheid en taakcomplexiteit lijkt in contracten van transacties met veel ex post problemen te ontbreken.

\section{Inleiding}

Dit artikel is gebaseerd op een onderzoek van Anderson en Dekker (2005) en richt zich op het ontwerp en de effectiviteit van contractuele beheersingsstructuren voor transacties tussen ondernemingen. In dit onderzoek wordt geanalyseerd

1 hoe contracten voor transacties tussen koper en leverancier worden vormgegeven;

Dr. H.C. Dekker is werkzaam als universitair hoofddocent aan de afdeling Accounting van de Vrije Universiteit te Amsterdam.
2 hoe karakteristieken van de transactie(partners) op contractontwerp van invloed zijn;

3 hoe meer en minder succesvolle transacties, waarbij succes is gemeten als de mate van ex post opgetreden problemen, verschillen in contractontwerp.

Het contract dat de partijen afsluiten en de beheersingsmechanismen die daarin worden gespecificeerd, worden daarbij gezien als een belangrijk onderdeel van de beheersingsstructuur die wordt ingezet om de transactie te beheersen ${ }^{1}$. De context waarin dit onderzoek is verricht bestaat uit een grote steekproef van transacties in informatietechnologie (IT)-producten en diensten tussen Nederlandse kleine en middelgrote ondernemingen en leveranciers van IT.

Samenwerkingsrelaties stellen ondernemingen in staat doelen te bereiken die zij zelf niet (tijdig) in staat zijn te realiseren (Madhok, 2002). Om de voordelen van samenwerkingsrelaties te kunnen realiseren, worden ondernemingen voor de uitdaging gesteld effectieve beheersingstructuren te ontwikkelen die zowel hun belangen waarborgen en voorzien in goede onderlinge afstemming met en coördinatie tussen partners (Dekker, 2004a). Uitbesteding van activiteiten, zoals van IT, is een veelvoorkomende vorm van samenwerking tussen ondernemingen en kan worden gezien als één van de meer complexe beslissingen waar managers in hun functie mee te maken hebben (Leiblein, Reuer en Dalsace, 2002). Om succes te waarborgen vergen deze uitbestedingsrelaties een beheersingsstructuur die is aangepast aan de aard van de activiteiten en de samenwerkende partners (Van der Meer-Kooistra en Vosselman, 2000). Vooral de mate waarin het uitbesteden van IT-producten en -diensten in de praktijk plaatsvindt en de complexiteit en risico's die daarmee samenhangen, maken het als onderzoekscontext zeer relevant. Het belang van goede contracten voor IT-transacties met een leverancier is ook evident gegeven berichten in de onderzoeksliteratuur dat IT-uitbesteding veelal niet ople- 
vert wat de uitbesteder ervan verwacht. Zo gaan deze uitbestedingen vaak gepaard met prestatieproblemen als te lage kwaliteit en functionaliteit, hoge kosten, matige tot slechte service, hoge afhankelijkheid van de leverancier en een verlies van kennis van en controle over kritische activiteiten (Barthelemy, 2001; King en Malhotra, 2000). Ook in het in dit artikel te bespreken onderzoek blijkt een substantieel deel van de onderzochte transacties gepaard te gaan met problemen ten aanzien van de geleverde IT-producten en bijbehorende diensten. Het ontstaan van dit soort problemen is veelal gerelateerd aan de informatieasymmetrie die aanwezig is tussen leverancier en koper, en de onzekerheid over de gewenste uitkomst en hoe die te bereiken. Vooral indien producten en diensten op maat worden ontwikkeld, spelen investeringen in specifieke kennis en activa en de benodigde afstemming tussen partijen een belangrijke rol in de complexiteit van het ontwerpen van een goede beheersingsstructuur. Dit thema van effectief contractontwerp onder complexe omstandigheden staat daarom centraal in het onderzoek. Gerelateerd aan de drie eerder genoemde doelen van de analyse zijn de volgende hoofdvragen gesteld om het onderzoek te structureren:

- Welke typen contractuele beheersingsmechanismen worden gebruikt om beheersing van transacties vorm te geven?

- Welke karakteristieken van de transactie(partners) gaan gepaard met het gebruik van deze beheersingsmechanismen?

- Welke karakteristieken van de transactie(partners) zijn gerelateerd aan de mate waarin transactieproblemen voorkomen?
- Is een (mis)match tussen deze karakteristieken en de gebruikte beheersingsmechanismen gerelateerd aan de mate van transactieproblemen?

Het model dat aan deze vragen ten grondslag ligt, is in figuur 1 samengevat, waarbij de tekens achter de variabelen de richting van hun verwachte effect weergeven. Tevens zijn voor het overzicht de in het onderzoek gevonden dimensies van contracten in de figuur cursief weergeven, welke in de volgende paragraaf in meer detail aan bod komen. De diverse onderdelen van het model worden in de hierna volgende paragrafen ook in meer detail toegelicht.

Het model geeft aan dat indien de genoemde transactiekarakteristieken, bijvoorbeeld specificiteit van de transactie, in hogere mate anwezig zijn, de kans op transactieproblemen toeneemt en daarom een meer omvangrijk contract met meer beheersingsmechanismen nodig zal zijn. Indien het contract echter onvoldoende rekening houdt met deze specificiteit neemt de kans op ex post transactieproblemen toe. De eerste twee onderzoeksvragen richten zich dus op de vormgeving van contracten en factoren die dat beïnvloeden; in de figuur weergegeven door middel van de eerste twee blokken met variabelen. Daarbij wordt tevens verwacht dat meer omvangrijke contracten leiden tot hogere kosten van contracteren. De laatste twee onderzoeksvragen richten zich op het daadwerkelijk ontstaan van transactieproblemen en omstandigheden waaronder contractuele beheersingsstructuren meer of minder succesvol zijn. Specifiek wordt daarbij gekeken naar de vraag of het contract goed is aangepast aan de verschillende karakteristieken van de

Figuur 1. Het onderzoeksmodel

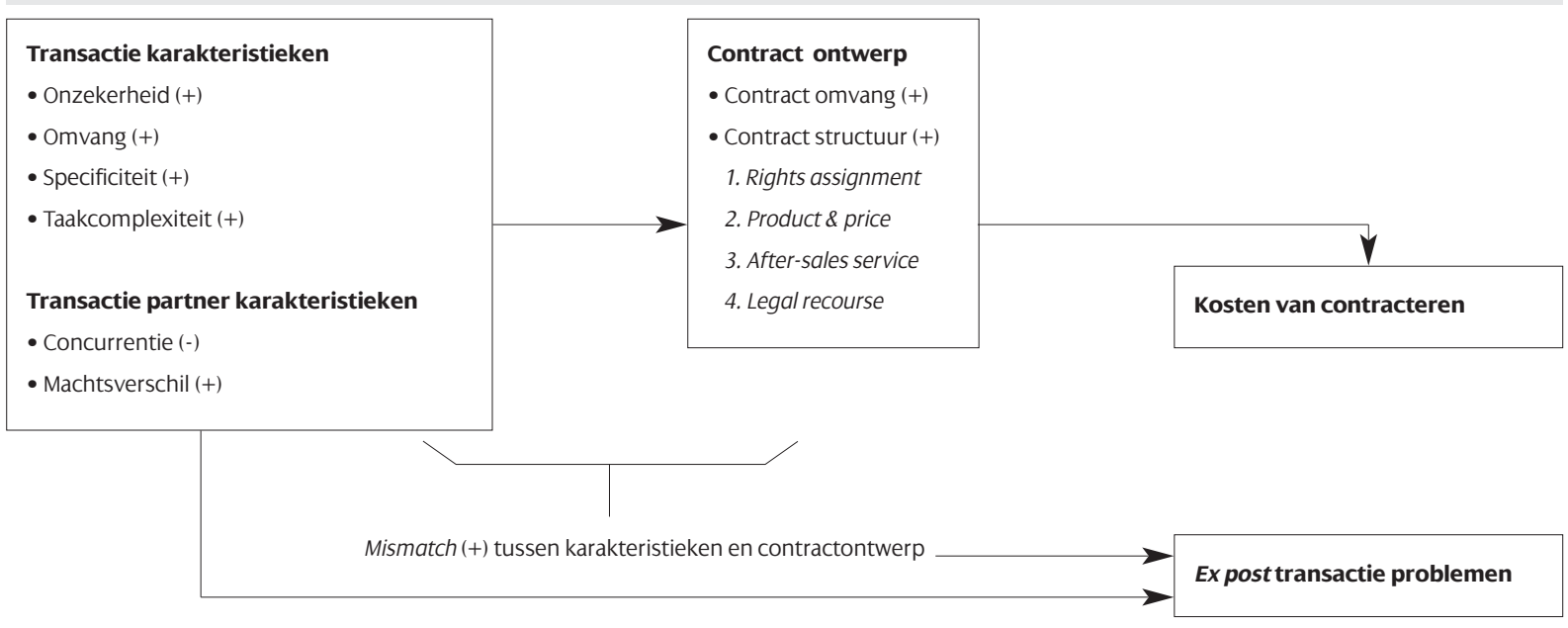


transactie(partners). Indien dit niet het geval is, bijvoorbeeld het contract houdt weinig rekening met de hoge specificiteit en onzekerheid van de transactie, dan is sprake van een mismatch, wat gepaard gaat met een hogere mate van transactieproblemen.

Uit de onderzoeksvragen wordt verder duidelijk dat de keuze voor uitbesteden of zelf produceren niet centraal staat in het onderzoek. Een belangrijke reden hiervoor is dat de onderzochte ondernemingen hierin weinig keus hebben: zij zijn meestal eenvoudigweg niet in staat de IT zelf te ontwikkelen, vooral niet als die in omvang en complexiteit toeneemt. Hooguit kunnen zij dan nog kiezen voor het niet aangaan van de transactie, waarbij de benodigde IT dus in het geheel niet wordt verkregen. Tevens is in de afgelopen decennia al veel onderzoek verricht naar de keuze voor de zogenoemde make-or-buy beslissing (of tussen markt, hiërarchie en de hybride vorm van samenwerking en allianties) en welke factoren hierop invloed uitoefenen. Minder onderzoek is verricht naar de keuze voor specifieke beheersingsmechanismen die worden gebruikt indien eenmaal is gekozen voor uitbesteding, een thema dat vooral in de laatste jaren meer belangstelling ontvangt in de accounting literatuur. In het bijzonder is in voorgaand onderzoek de effectiviteit van beheersingsmechanismen en -structuren voor samenwerkingsrelaties onderbelicht gebleven. Het in dit artikel te bespreken onderzoek probeert aan het vraagstuk van de keuze voor en gevolgen van beheersingsmechanismen voor uitbestedingsrelaties invulling te geven door een antwoord te zoeken op de bovenstaande vier vragen. Dit leidt dus tot inzicht in de architectuur van (effectieve) uitbestedingscontracten. Vooral de laatst gestelde vraag richt zich specifiek op de effectiviteit van contracten tussen transactiepartners. Daarmee relateert het aan een in de praktijk belangrijke vraagstelling, aangezien geïdentificeerd wordt hoe succesvolle en minder succesvolle transacties van elkaar verschillen in het gebruik van contractuele beheersingsmechanismen voor specifieke transactieomstandigheden.

De structuur van dit artikel volgt de bovengenoemde vragen. In paragraaf 2 wordt eerst ingegaan op welke contractuele mechanismen door ondernemingen worden gebruikt voor de beheersing van hun transacties. In paragraaf 3 wordt geanalyseerd onder welke omstandigheden deze mechanismen worden gebruikt. In paragraaf 4 wordt vervolgens onderzocht hoe meer succesvolle transacties verschillen van minder succesvolle transacties in het gebruik van beheersingsmechanismen. Tot slot wordt in paragraaf 5 een conclusie getrokken, waarbij ook enkele suggesties voor toekomstig onderzoek aan bod komen.

\section{Beheersingsstructuren voor IT-transacties}

Het onderzoek waar dit artikel over bericht, is gebaseerd op een bestaande omvangrijke database van transacties tussen kopers en leveranciers van IT-producten en -services (Batenburg en Raub, 1995)². Deze database omvat 971 IT-transacties waarvan de gegevens in 1995 zijn verzameld via een uitgebreide vragenlijst afgenomen bij 788 kopende ondernemingen ${ }^{3}$. De kopende ondernemingen varieerden in omvang van klein tot middelgroot (minimaal vijf en maximaal 200 medewerkers) en de verkopende partijen van klein tot zeer groot. De inhoud van de transacties betrof zowel IT-producten (van standaardsoftware tot op maat gemaakte software, en hardware als PC's, netwerken, mainframes en computergestuurde machines) als IT-diensten (bijvoorbeeld scholing, instructie, advies en ontwerp). Veelal bestonden de transacties uit een diversiteit aan producten en diensten die sterk varieerden in complexiteit. Gegeven de omvang van de kopende ondernemingen waren deze transacties voor hen al snel een belangrijke investeringsbeslissing. Voor elk van deze transacties heeft een uitgebreide meting plaatsgevonden van onderwerpen waarover de transactiepartners afspraken hebben gemaakt door middel van een lijst van 24 mogelijk in het contract voorkomende onderwerpen. Daarbij viel de hoge mate van variatie in gebruik van afspraken op: voor sommige transacties werd, op de prijs na, vrijwel geen enkele afspraak gemaakt, terwijl voor andere transacties alle 24 typen afspraken voorkwamen. Op deze lijst met mogelijke contractafspraken is een exploratieve factoranalyse uitgevoerd om veel voorkomende combinaties (dimensies) van afspraken te destilleren. Met andere woorden: worden afspraken gebruikt in veel voorkomende combinaties met eenzelfde type doel? Dit bleek inderdaad het geval waarbij de analyse vier dimensies van beheersing weergaf, als volgt gelabeld:

- Rights assignment: deze dimensie betreft het toewijzen van eigendoms- en beslissingsrechten, zoals afspraken over intellectueel eigendom, restricties op gebruik en openbaarmaking van informatie en technologie, gezamenlijk management van de transactie en het delen van R\&D-kosten.

- Product \& price: deze dimensie betreft afspraken ten aanzien van de basisvoorwaarden van de transactie, zoals prijsbepaling en -wijzigingen, levertijden en productspecificaties.

- After-sales service: deze dimensie betreft afspraken 
over dienstverlening nadat levering heeft plaatsgevonden, zoals servicetermijnen, onderhoud en garantie.

- Legal recourse: deze dimensie betreft hoe de partijen omgaan met mogelijke conflicten die tijdens of na de transactie ontstaan, zoals afspraken over ansprakelijkheid, overmacht, arbitrage, sancties en ontbinding van de transactie.

Deze uitkomst van de factoranalyse deelt contractafspraken dus in naar in de praktijk voorkomende combinaties met een soortgelijk doel van beheersing. Daarmee valt de uitkomst goed te relateren aan bestaande raamwerken van beheersing, zoals van Jensen en Meckling (1992). Zij maken onderscheid tussen drie functies van management control systemen:

1 prestatiemeting;

2 beloningen en sancties;

3 het toewijzen van beslissingsrechten en verantwoordelijkheden.

De dimensies die voortkomen uit bovenstaande factoruitkomst vallen als volgt te plaatsen in dit raamwerk. Product \& Price en After sales service specificeren verwachte performance en de eerste factor specificeert ook beloningen voor goede prestaties. Rights assignment komt overeen met het toewijzen van beslissingsrechten en verantwoordelijkheden en legal recourse relateert vooral aan sancties en beslissingen in geval van ontoereikende prestaties. Deze dimensies van de onderzochte IT-contracten lijken dus bekende functies van management control systemen te weerspiegelen.

Interessant in deze factoruitkomst is ook dat het vormen van beheersing betreft waarbij alle vier vormen in meer of mindere mate gezamenlijk worden gebruikt om een transactie te beheersen. Zo worden voor een transactie veelal afspraken gemaakt ten aanzien van de basisvoorwaarden (product, prijs en aftersales service), worden rechten toegewezen aan partijen en worden afspraken gemaakt over hoe om te gaan met eventuele conflictsituaties. Een alternatief mogelijke uitkomst van deze analyse had kunnen resulteren in verschillende combinaties van beheersingsmechanismen die voor verschillende typen transacties worden gekozen, waarbij de verschillende combinaties substituten van elkaar zijn. In dit onderzoek is echter sprake van complementariteit tussen de vier verschillende dimensies van beheersing.

Alhoewel meer uitgebreide contracten partijen in staat stellen een hogere mate van beheersing over de transactie te verkrijgen, is het onderhandelen en ont- werpen van contracten een kostbare aangelegenheid. Een analyse naar de kosten van de afgesloten contracten geeft dit ook duidelijk weer: naarmate de contracten in aantal afspraken toenemen, nemen de kosten van het contracteren toe. Deze kosten werden gemeten als de tijd die is besteed aan het onderhandelen over en opstellen van het contract. Onder de reële veronderstelling dat ondernemingen niet onbeperkt tijd en geld willen besteden aan het creëren van betere maar duurdere contracten, impliceert dit dat er een optimum is op welk punt de marginale kosten van contracteren de marginale voordelen overtreffen. Op dat punt zal het contract logischerwijs niet verder worden uitgebreid. Dit leidt er dus toe dat veel contracten incompleet zijn ten aanzien van afspraken en het afdekken van mogelijke risico's, en zij zodoende ruimte laten voor het ontstaan van transactieproblemen. De volgende vraag die dan ook uit de voorgaande analyse opkomt, is welke omstandigheden ertoe leiden dat ondernemingen meer uitgebreide contracten ontwerpen, waarvan de verwachte voordelen hoger zijn dan de benodigde investering.

\section{Het gebruik van beheersingsmechanismen voor transacties}

$\mathrm{Na}$ het identificeren van de dimensies van beheersing die voorkomen in contractafspraken was de tweede stap in het onderzoek het identificeren welke transactiekarakteristieken het gebruik van contractafspraken beïnvloeden. Daarbij werden de contracten op twee manieren geanalyseerd, zoals ook weergegeven in figuur 1:

1 Naar totale contractomvang (het absoluut aantal afspraken); dus welke factoren bepalen het aantal gebruikte contractafspraken?

2 Naar contractdimensie; dus welke factoren bepalen de mate waarin elk van de vier eerder besproken contractdimensies (in samenhang met de andere drie dimensies) wordt gebruikt?

In deze analyses is gekeken naar een zestal factoren waarvan werd verwacht dat zij de behoefte aan beheersing beïnvloeden. De eerste vier factoren, afkomstig uit de transactiekostentheorie (Milgrom en Roberts, 1992; Williamson, 1985), zijn gerelateerd aan de transactie en beïnvloeden transactierisico's en informatieasymmetrie tussen de partijen: financieel volume, specificiteit, onzekerheid en taakcomplexiteit. De laatste twee factoren, gebaseerd op het strategisch raamwerk van Porter (1980), zijn gerelateerd aan de transactiepartners: concurrentie en machtsverschillen. Deze factoren en de verwachtingen hoe zij van 
invloed zijn op contractontwerp worden hieronder kort behandeld.

- Onzekerheid reflecteert de moeilijkheid om vooraf de producten en diensten in de transactie goed te definiëren en achteraf goed te meten. Meer onzekerheid levert behoefte aan meer beheersing, alhoewel onzekerheid tegelijkertijd het ontwerpen van formele beheersingsstructuren (als contracten) bemoeilijkt. In het onderzoek werd voor de factor onzekerheid specifiek gekeken naar de moeilijkheid voor de koper om de kwaliteit van het geleverde product te evalueren en om producten en alternatieve leveranciers met elkaar te vergelijken.

- Volume betreft de totale financiële contractomvang. Naarmate de omvang van de investering voor de koper toeneemt, zal deze zich meer willen beschermen, aangezien het potentiële verlies toeneemt.

- Specificiteit van een transactie geeft in het onderzoek de kosten weer die voor de koper zouden ontstaan indien het product van de leverancier zou falen en overgegaan moet worden op een ander product van een andere leverancier. Naarmate de transactie meer specifiek wordt voor de koper, zoals in het geval van op maat ontwikkelde software, zullen deze faalkosten en de moeilijkheid van 'switchen' toenemen. Zo kan het bij het switchen naar andere software nodig zijn medewerkers met specifieke kennis van de huidige software opnieuw op te leiden, kunnen productieprocessen tot stilstand komen en moeten data eventueel opnieuw worden ingevoerd. Zodoende geeft deze factor een indicatie van de blootstelling aan potentieel opportunistisch gedrag van de leverancier.

- Taakcomplexiteit relateert aan de complexiteit van de transactie en het aantal verschillende typen producten en diensten in de transactie. Naarmate de complexiteit en de diversiteit van de transactieonderdelen toenemen, neemt ook de interdependentie en behoefte aan coördinatie tussen de partijen toe. Tevens leidt taakcomplexiteit tot moeilijkheden bij het toewijzen van een oorzaak of schuld bij problemen die ontstaan. Toenemende taakcomplexiteit zal daarom een meer uitgebreide beheersingsstructuur vergen om coördinatie tussen partners te faciliteren en verantwoordelijkheden goed te definiëren.

- Concurrentie betreft het aantal alternatieve leveranciers en producten die beschikbaar waren voor de koper ten tijde van de keuze voor de leverancier. Meer concurrentie voor deze leverancier leidt ertoe dat de koper juist minder beheersingsmechanismen nodig zal hebben wegens de dreiging van leverancier en product te wisselen.

- Machtsverschil tussen koper en leverancier, ten slotte, relateert aan de mate waarin de koper zich contractueel wil beschermen tegen potentieel misbruik van een machtspositie door de leverancier. Een groter machtsvoordeel voor de leverancier, en dus meer afhankelijkheid voor de koper, wordt verwacht te leiden tot het gebruik van meer contractafspraken.

De invloed van deze zes transactie(partner)factoren op contractomvang en contractdimensies, zoals weergegeven in figuur 1, is geanalyseerd door middel van de statistische techniek structural equation modeling. Met deze techniek kunnen meerdere relaties (zoals de invloed op de vier contractdimensies) tegelijk worden geschat en kan ook rekening worden gehouden met onderlinge samenhang tussen de zes factoren en tussen de vier contractdimensies. De resultaten van de analyse van de totale contractomvang duidden aan dat met name de financiële omvang van de transactie bepalend is voor het aantal afspraken die transactiepartners met elkaar maken. Tevens neemt het aantal contractafspraken toe met de specificiteit en taakcomplexiteit van de transactie. Voor de overige drie factoren, onzekerheid, concurrentie en machtsverschillen, werd geen statistisch significant effect gevonden.

De analyse naar de invloed van deze zes transactie(partner)factoren op de vier contractdimensies bood echter een meer genuanceerd beeld. Hieruit bleek dat alhoewel financieel volume gepaard gaat met meer afspraken op alle vier dimensies, de overige factoren meer aan individuele contractdimensies zijn gerelateerd. Specificiteit en taakcomplexiteit van de transactie blijken vooral te leiden tot meer afspraken op het gebied van eigendoms- en beslissingsrechten. Daarnaast gaat specificiteit gepaard met meer afspraken over hoe potentiële conflicten op te lossen ('legal recourse'). Het effect van meer concurrentie voor de leverancier blijkt tweeledig. Enerzijds lijkt concurrentie te helpen het aantal benodigde afspraken over eigendoms- en beslissingsrechten te beperken; deze nemen af naarmate concurrentie toeneemt. Echter, anderzijds leidt meer concurrentie ook tot een toename van afspraken over product en prijs. Deze tegengestelde effecten verklaren ook waarom concurrentie geen effect heeft op de totale contractomvang in de eerdere analyse, maar dus wel op dimensies daarvan. Machtsverschillen, ten slotte, leiden vooral tot een toename van afspraken over after-sales service en conflicthantering.

Eén factor, onzekerheid, blijkt geen invloed te hebben op zowel het gehele contract als op de individuele dimensies daarvan. Dit komt niet geheel als verrassing, aangezien onzekerheid een factor is die, ondanks 
dat zij een behoefte aan bescherming en afstemming genereert, juist een effectief contractontwerp in de weg staat. Immers, hoe kunnen partijen goede afspraken maken over processen en uitkomsten als zij maar beperkt inzicht hebben in die processen en gewenste uitkomsten? Dus wellicht zijn voor de meeste ondernemingen de kosten van contracteren voor onzekerheid te hoog om daar daadwerkelijk goede afspraken over te maken ${ }^{4}$.

Het totaalbeeld dat uit deze analyse naar voren komt is dat contracten door ondernemingen conform de verwachtingen worden afgestemd op de aard van de transactie en haar partners. Vooral naarmate financiële omvang, specificiteit en taakcomplexiteit van de transactie toenemen, worden meer afspraken gemaakt. Deze conclusies zijn gebaseerd op de gehele steekproef van onderzochte transacties, ongeacht de mate van succes die met de transactie werd behaald. De vraag die zich daarom op basis van deze resultaten logischerwijs aandient, is of en hoe succesvolle transacties verschillen van minder succesvolle transacties. Vooral van belang is of zij verschillen in de mate waarin het contract is afgestemd op de verschillende transactiefactoren. Ofwel: gaat een goede match tussen het contract en de transactiekenmerken gepaard met meer succes van de transactie?

\section{De effectiviteit van contractstructuren voor transacties}

In het onderzoek werd het succes van een transactie beoordeeld aan de hand van de mate waarin elf typen problemen waren voorgekomen ten aanzien van het geleverde product of de bijbehorende service. Voorbeelden van voorkomende problemen zijn te late oplevering, kostenoverschrijdingen, een incompleet of niet functioneel product, te late of inadequate ondersteuning en response, en incomplete documentatie bij het geleverde product. Problemen met product en service bleken in de steekproef veel voorkomend: bij 256 van de 858 onderzochte transacties werd voor één of meerdere van de mogelijke problemen een 4 of 5 gescoord op een vijfpuntschaal. Deze scores geven aan dat dit problemen waren van (zeer) serieuze aard. Deze hoge mate van daadwerkelijk ondervonden problemen maakt het interessant te analyseren hoe transacties met veel problemen verschillen van transacties met weinig problemen.

Voordat met deze analyse is aangevangen, is eerst een analyse verricht of de mate van ondervonden transactieproblemen samenhangt met de transactiekenmerken, zoals weergegeven door de onderste pijl in figuur 1 (deze analyse laat dus het gebruikte contract buiten beschouwing). Hieruit bleek dat transactieproblemen vooral gepaard gaan met hoge onzekerheid, taakcomplexiteit en machtsverschillen tussen leverancier en koper. Vooral de eerste bevinding is interessant, omdat juist de factor onzekerheid, die geen invloed uitoefende op contractontwerp, de belangrijkste factor blijkt in het verklaren van achteraf opgetreden problemen. Blijkbaar is het inderdaad moeilijk om goede contracten te ontwerpen die effectief omgaan met onzekerheid. Of de kosten om dit te doen zijn zo hoog dat ondernemingen liever het risico lopen dat gepaard gaat met onzekerheid, wat zich voor veel transacties dus uiteindelijk ook uit in een hogere mate van voorgekomen problemen.

Gegeven dat ex post transactieproblemen inderdaad samenhangen met karakteristieken van de transactie en haar partners is de meer fundamentele vraag of contracten die aangepast zijn aan deze karakteristieken uiteindelijk gepaard gaan met minder problemen dan contracten die daar minder goed op zijn aangepast. Om dit te onderzoeken werd de database gesplitst in transacties waarbij een hoge mate van problemen was voorgekomen en transacties waarbij weinig problemen waren ontstaan. Deze twee groepen werden vervolgens vergeleken op de mate waarin het contract was aangepast op de karakteristieken van de transactie(partners). Dit werd gedaan voor zowel de totale contractomvang als de vier contractdimensies en is in figuur 1 geillustreerd door de pijl van mismatch naar transactieproblemen ${ }^{5}$. Beginnende bij de totale contractomvang werden direct evidente verschillen tussen de groepen transacties met veel en weinig problemen gevonden. Transacties met veel ex post problemen bleken gebruik te maken van contracten die vooral in aantal afspraken toenemen met een groter financieel transactievolume en met meer specificiteit van de transactiecomponenten. Transacties met weinig ex post problemen hielden in het contract ook rekening met deze twee factoren, echter in minder sterke mate. In plaats daarvan namen contracten van deze groep ook in antal afspraken toe met de onzekerheid en taakcomplexiteit van de transactie. Waar contracten van de 'probleemtransacties' dus vooral lijken te zijn aangepast op de financiële risico's die de koper percipieert te lopen, houden contracten van transacties zonder veel problemen daarnaast ook rekening met de onzekerheden, technische complexiteit en daarmee samenhangende benodigde afstemming tussen de partijen. De hierop aansluitende analyse van verschillen tussen de twee groepen op hoe de zes factoren samenhangen met de vier contractdimensies bevestigde deze uitkomst ook voor de indivi- 
duele contractdimensies, waarbij nog één markant verschil evident werd. Terwijl bij transacties met weinig ex post problemen concurrentie tussen leveranciers vooral werd gebruikt om het aantal afspraken op het gebied van beslissings- en eigendomsrechten en aftersales service te beperken, bleken transacties met veel ex post problemen concurrentie juist te gebruiken om meer gedetailleerde afspraken te maken op gebied van prijs en product.

De rol van onzekerheid blijkt uit deze analyse ook meer genuanceerd te zijn dan de eerdere analyse voor de gehele steekproef suggereerde, waaruit het leek dat onzekerheid geen enkel effect had op contractontwerp. Bij toenemende onzekerheid bleken transacties met weinig ex post problemen meer contractafspraken te maken op het gebied van product en prijs, after-sales service en conflicthantering ${ }^{6}$. Misschien zijn de ondernemingen die minder problemen hebben ervaren met de transactie in staat geweest meer effectief met onzekerheid om te gaan in het contractontwerp en/of hebben zij de hogere kosten daarvan voor lief genomen. Dit zijn vragen waar toekomstig onderzoek antwoorden voor zou kunnen verschaffen. Uit het onderzoek wordt echter wel duidelijk dat de transacties waarvan het contract rekening hield met onzekerheid met minder ex post problemen gepaard gingen dan de transacties waarbij dit niet het geval was.

\section{Conclusie}

Het in dit artikel besproken onderzoek van Anderson en Dekker (2005) geeft inzicht in factoren die invloed uitoefenen op contractuele beheersingsstructuren voor transacties tussen ondernemingen en, meer belangrijk, hoe contracten van succesvolle transacties aangepast zijn aan deze factoren. Deze factoren zijn gerelateerd aan zowel de transactie als de partners die daarin deelnemen en leiden tot beheersingsproblemen ten aanzien van potentieel opportunisme en benodigde onderlinge afstemming. Als geheel genomen bevestigen de resultaten van het onderzoek de verwachting dat contracten worden aangepast aan karakteristieken van de transactie en haar partners. Alhoewel voorgaande studies in andere contexten en met andere variabelen ook tot soortgelijke conclusies zijn gekomen, is een meer belangrijke bevinding van de studie dat succes van transacties inderdaad blijkt samen te hangen met de mate waarin gebruikte contracten rekening houden met de kenmerken van de transactie(partners). Dit lijkt ook voor de praktijk een waardevolle conclusie. Vooral van belang hierbij, zo suggereert het onderzoek, is dat contracten zich niet alleen richten op de financiële risico's die kopers lopen, maar ook op de onzekerheden en technische complexiteiten van de transactie. De rol van concurrentie in de markt van de leverancier blijkt in dit onderzoek vooral waardevol om transactieproblemen te voorkomen en contractafspraken te beperken, in plaats van het verkrijgen van meer uitgebreide prijsen productafspraken. Uiteraard levert het creëren van een 'goed' contract nog geen waterdichte garantie voor succes, maar het onderzoek geeft aan dat het wel een middel kan zijn om de kansen op succes te verhogen.

Alhoewel dit onderzoek een duidelijk beeld schetst van de architectuur van (effectieve) contracten voor transacties zijn andere belangrijke factoren, zoals vertrouwen tussen de transactiepartners en het partnerselectieproces dat vooraf gaat aan de contractfase, buiten beschouwing gebleven. Dit zijn factoren die ook een substantiële invloed kunnen uitoefenen op contractontwerp, vooral indien onzekerheden en risico's van een transactie toenemen. Zo geeft een studie van Gulati (1995) aan dat vertrouwen tussen partners voortkomend uit voorgaande gezamenlijke allianties er vaak toe leidt dat zij voor nieuwe allianties minder uitgebreide beheersingsstructuren gebruiken. Alhoewel dit evident leidt tot meer efficiënt gebruik van middelen, blijft de vraag hoe succesvol op vertrouwen gebaseerde samenwerkingsrelaties zijn vooralsnog grotendeels open. Ook het partnerselectieproces dat aan contractontwerp vooraf gaat kan invloed op ontwerp en gebruik van beheersingsstructuren uitoefenen. Zo kunnen ondernemingen tijdens het selectieproces meer kennis van de transactie(omgeving) en ervaring met verschillende leveranciers opdoen, wat vervolgens kan leiden tot meer vertrouwen in de intenties en competenties van een potentiële partner. Dit vertrouwen stelt hen in staat minder uitgebreide beheersingsstructuren te ontwerpen. Anderzijds kan deze kennis ook juist leiden tot het efficiënt ontwerpen van meer omvangrijke (en meer effectieve?) contracten, waarbij het partnerselectieproces dus fungeert als belangrijk leerproces (Dekker, 2004b). Dit zijn factoren die in vervolgonderzoek zeker aan bod moeten (blijven) komen, waarbij vooral de relatie met het succes of falen van transacties en samenwerkingsverbanden de aandacht verdient.

Het in dit artikel besproken onderzoek heeft specifiek betrekking op transacties in informatietechnologie. Het is derhalve ook nog een open vraag of de bevindingen en conclusies ook opgeld doen voor uitbestedingsrelaties met activiteiten van andere aard, zoals productie- en onderhoudsactiviteiten. Alhoewel het 
onderzoek heeft plaatsgevonden binnen een IT-context, zijn veel van de onderzochte variabelen generiek van aard. Zij geven algemene beheersingsproblemen weer die ontstaan zodra ondernemingen samenwerkingsrelaties met elkaar aangaan, zoals het risico van opportunistisch gedrag en benodigde coördinatie tussen partijen (Dekker, 2004a). Ook ten aanzien van de gebruikte beheersingsstructuren mag worden verwacht dat in andere typen uitbestedings- en samenwerkingsrelaties contracten met soortgelijke functies als gevonden in dit onderzoek worden gebruikt. Om dit vast te stellen is vervolgonderzoek naar de architectuur en effectiviteit van beheersingsstructuren in samenwerkingsverbanden onontbeerlijk.

\section{Literatuur}

Anderson, S.W. en H.C. Dekker, (2005), Management Control for Market Transactions: The Relation Between Transaction Characteristics, Incomplete Contract Design and Subsequent Performance, forthcoming in Management Science.

Barthelemy J., (2001), The hidden costs of IT outsourcing, in: Sloan Management Review, vol. 42, no. 3, Spring, pp. 60-69.

Batenburg, R.S. en W. Raub, (1995), The external management of automation 1995 [data set], Utrecht University.

Dekker, H.C., (2004a), Control of inter-organizational relationships: evidence on appropriation concerns and coordination requirements, in: Accounting, Organizations and Society, vol. 29, no. 1, January, pp. 27-49.

Dekker, H.C., (2004b), Partner selection and governance design in interfirm relationships, Working paper, Vrije Universiteit Amsterdam.

Gulati, R., (1995), Does Familiarity Breed Trust? The Implications of Repeated Ties for Contractual Choice in Alliances, in: Academy of Management Journal, vol. 38, no. 1, pp. 85-113.

Jensen, M.C. en W.H. Meckling, (1992), Specific and General Knowledge, and Organizational Structure, in: L. Werin en H. Wijkander (eds.), Contract Economics, Oxford (Blackwell), pp. 251-274.

King, W.R. en Y. Malhotra, (2000), Developing a framework for analyzing IS outsourcing, in: Information \& Management, vol. 37, no. 6, pp. 323-334.

Leiblein, M.J., J.J. Reuer en F. Dalsace, (2002), Do make or buy decisions matter? The influence of organizational governance on technological performance, in: Strategic Management Journal, vol. 23, no. 9, pp. 817-833.

Madhok, A., (2002), Reassessing the Fundamentals and beyond: Ronald Coase, the transaction cost and resource-based theories of the firm and the institutional structure of production, in: Strategic Management Journal, vol. 23, no. 6, pp. 535-550.

Meer-Kooistra, J. van der en E.J.G. Vosselman, (2000), Management control of interfirm transactional relationships: the case of industrial renovation and maintenance, in: Accounting, Organizations and Society, vol. 25 , no. 1, pp. 51-77.

Milgrom, P. en J. Roberts, (1992), Economics, Organization and Management, Prentice-Hall, Englewood Cliffs, NJ.

Porter, M.E., (1980), Competitive strategy: techniques for analyzing industries and competitors, Free Press, New York.
Williamson, O.E., (1985), The economic institutions of capitalism, Free Press, New York.

\section{Noten}

1 Andere mechanismen die deel uit kunnen maken van beheersingstructuren, zoals niet-contractuele coördinatiemechanismen en informele afspraken (Dekker, 2004a), worden in dit onderzoek dus buiten beschouwing gelaten.

2 Na het verwijderen van transacties met ontbrekende gegevens is voor het onderzoek gebruikgemaakt van 858 transacties uit deze database. Alhoewel in circa $50 \%$ van de gevallen de partijen in het verleden al met elkaar hadden gehandeld, betroffen de transacties voornamelijk onafhankelijke transacties. De effecten van het hebben van eerdere ervaringen met de leverancier op contractontwerp worden behandeld in Dekker (2004b) en staan niet centraal in het huidige onderzoek.

3 In een aantal gevallen werden door respondenten twee enquêtes ingevuld die betrekking hadden op verschillende transacties.

4 Men kan zich hierbij ook inbeelden dat zeer onzekere en risicovolle transacties om deze reden in het geheel niet door ondernemingen worden aangegaan en zij daarom ook niet in de steekproef van onderzochte transacties voorkomen, of dat zij alleen worden aangegaan als het vertrouwen tussen partners hoog genoeg is.

5 In de analyse werd gecontroleerd voor de vraag of de zes karakteristieken in de groepen met en zonder veel problemen dezelfde betekenis hadden, wat inderdaad het geval bleek te zijn. De resultaten ten aanzien van verschillen tussen de groepen komen dus niet voort uit de mogelijkheid dat de transactie(partner)karakteristieken niet dezelfde constructen representeren binnen de groepen.

6 Ook op het gebied van eigendoms- en beslissingsrechten werden binnen deze groep meer afspraken gemaakt als onzekerheid toenam, maar dit effect was echter niet statistisch significant op 10\%-niveau. 